University of Nebraska - Lincoln

DigitalCommons@University of Nebraska - Lincoln

West Central Research and Extension Center, North Platte

Agricultural Research Division of IANR

$5-2013$

\title{
A scan of the horizon indicates conservation is changing, but are conservation-related societies?
}

Stephen L. Young

University of Nebraska - Lincoln, steve.young@usu.edu

Follow this and additional works at: https://digitalcommons.unl.edu/westcentresext

Young, Stephen L., "A scan of the horizon indicates conservation is changing, but are conservation-related societies?" (2013). West Central Research and Extension Center, North Platte. 75.

https://digitalcommons.unl.edu/westcentresext/75

This Article is brought to you for free and open access by the Agricultural Research Division of IANR at DigitalCommons@University of Nebraska - Lincoln. It has been accepted for inclusion in West Central Research and Extension Center, North Platte by an authorized administrator of DigitalCommons@University of Nebraska - Lincoln. 


\title{
VIEWPOINT A scan of the horizon indicates conservation is changing, but are conservation-related societies?
}

\author{
Stephen L. Young
}

I $\mathrm{n}$ societies, organizations, and institutions, we often look backwards to understand the way forward. While this can be important, it can also be detrimental if done too often or becomes an over-relied upon practice. At major international car shows, companies display the make and model for those cars that have done well in the past, but the biggest attraction is the cars of the future (figure 1). At the biggest agricultural trade shows in the country, the equipment that has the biggest audience is the newest or most futuristic (figure 2). When we want to develop new collaborations, do we go to classmates.com and look up old high school buddies? No, we look for new opportunities through occupations, societies, or programs. So, when it comes to conservation, shouldn't we be doing the same thing-looking forward and not looking in the rearview mirror? Shouldn't we be looking ahead, far ahead to be able to see new challenges and the potential for solutions to current problems? While I am not arguing against the use of sound practices and policies for conservation of agricultural and natural resources, I am advocating for a more in depth look at what might be on the horizon for conservation and what changes are occurring in many of the societies and organizations that focus on or are involved in conservation.

Conservation has many definitions. Conserving resources, both financial and natural, is often achieved by making responsible decisions that prevent excessiveness and overuse, which result in depletion of supplies for current and future generations. In terms of landscapes, conservation has traditionally sought to keep them from changing or to at least change them back to the way they used to be (Aspen Institute 2012). Yet, we know that ecosystems are dynamic, even our most highly managed ones, and to "put

Stephen L. Young is weed ecologist at the West Central Research and Extension Center, University of Nebraska-Lincoln, North Platte, Nebraska. things back" is not possible or attainable no matter what the investment. New goals for conservation include a range of activities-from preventing extinctions to providing resources and infrastructure for human flourishing, to preserving culturally significant landscapes, to building resiliency into climate change (Aspen Institute 2012). Is it time for a new definition of conservation? Or, maybe use a different metric to measure the outcomes and emphasize the resilience of nature and its capacity to provide humans with the essential services they need for survival and well-being (Aspen Institute 2012). Ultimately, being able to accept what we have and what we have been able to preserve and determining how to improve the natural capital is what conservation is about and part of Aldo Leopold's description of a state of harmony between man and land.

If conservation in the 21 st century is different from previous time periods, how much do societies and organizations (and individuals) need to change? The mission of the Soil and Water Conservation Society (SWCS) is to foster the science and art of conservation that targets soil, water, and related natural resources on working lands. This mission is pursued through a combination of research, education, and advocacy activities and special projects designed to improve the practice and policy of conservation. Ultimately, SWCS aims for the development of conservation practices and systems that bring science and professional judgment to bear in shaping local, state, provincial, and federal policy. The SWCS is one of several societies that is focused on conservation of natural resources, but how much does that focus change or need to change considering that conservation of the 21st century is not the same as in previous periods? Is there enough latitude within conservation-related societies to account for this change, and if so, what is the current status? Finally, are these societies forward looking enough to be able to lead in addressing challenges on the horizon in the near and far future?

\section{Figure 1}

Car of the future (Studio 360 2010).

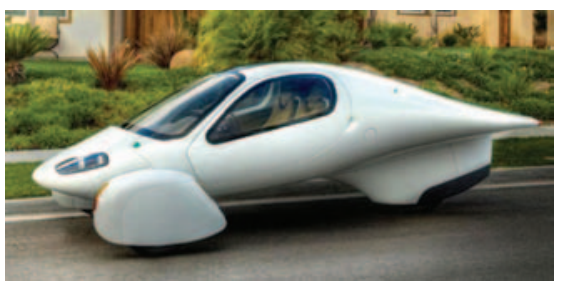

\section{Figure 2}

Agricultural implement of the future (Interempresas 2012).

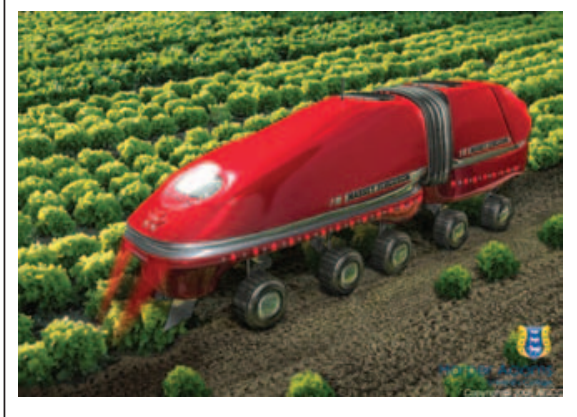

At this point, it is important to define what looking into the future means in terms of identifying what lies on the horizon. One approach to looking ahead is horizon scanning, which is the systematic search for, and examination of, potential threats, opportunities, and developments that are not widely recognized (Sutherland et al.2012). It is the first step in identifying, analyzing, and communicating hypotheses or insights about the future. By projecting multiple future scenarios, an organization or society has a greater ability to respond if the projections are accurate.

Prior to investigating how well conservation-related societies have done in looking into the future, we need to assess their track record in addressing conservation issues overall. For the sake of brevity and remaining within the constraints of this section, only the largest conservationrelated societies (e.g., Ecological Society of America [ESA], Society for Conservation Biology [SCB], and SWCS) and the Journal of Sustainable Agriculture (JSA) will be analyzed. A search of ESA, SCB, and SWCS journals and JSA for articles 
from the earliest to the most recent was done using available records for each journal, which varied from 17 to 32 years. The search terms "conservation,"“soil,"“water," "natural resources," and "agriculture" were all included in the analysis (figures $3 \mathrm{a}$ and $3 \mathrm{~b})$. This was not an exhaustive compilation and statistics were not performed on the data, but it does provide some insight into how each society and JSA has contributed to the production of papers on issues related to conserving natural resources and agriculture through publishing research studies on environmental conditions, policy development, economics, or management. The SWCS had the highest total number of articles $(1,482)$ in a 32-year period that have addressed conservation topics related to the five search terms. The others had fewer than 550 articles, but their period of records was 17 years (ESA), 26 years (SCB), and 23 years (JSA). The average number of articles produced over each period was still highest for the SWCS (46.3 per year), but ESA was close with 31.8 per year.

This analysis of major conservationrelated journals does not account for articles that used other key words besides the ones chosen above. In addition, analyzing four journals omits many publications produced by smaller or lesser known societies that have been in existence for longer or shorter periods of time. Primarily, these results are a subset of the otherwise large collection of published work, including non-peer reviewed, in the area of conservation. With this information, it appears that the four major conservation-related journals are doing well in addressing issues associated with conserving natural resources and agriculture, but what is not known is what percentage of these publications are focused on conservation issues of the future.

Recently, 15 horizon issues in ecology were identified as having potential to affect conservation of biological diversity (Sutherland et al. 2013). The aim of the ecological horizon scan was to identify issues that could affect the environment in ways that society might consider either positive or negative. Many of the issues identified are likely to have complex effects on society and underline the

\section{Figure 3}

(a) Total and (b) average number of articles published by major conservationrelated societies (Soil and Water Conservation Society [SWCS], Ecological Society of America [ESA], Society for Conservation Biology [SCB]) and the Journal of Sustainable Agriculture (JSA).

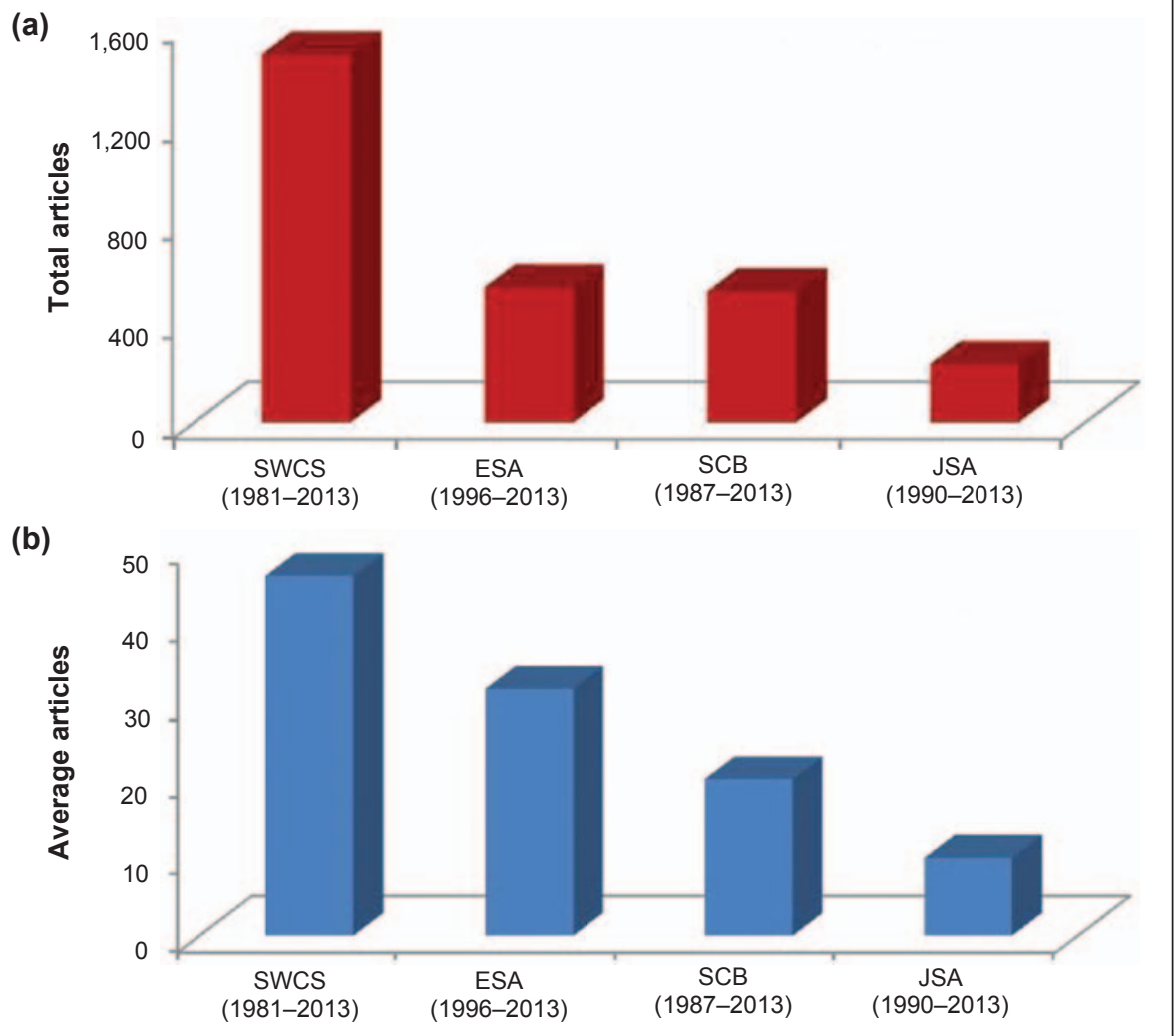

changing roles of, and approaches used by, conservation professionals today. This further reflects the new conservation goals identified earlier and the changes that are occurring or have occurred in the term "conservation" around the globe.

Among the top issues identified by Sutherland et al. (2013) as having a potential effect on biological diversity is rapid growth of concentrated solar power, accelerated water cycle, and species loss (table 1). In addition to these, the lesser known issues in ecology may not be directly related to conservation; therefore, it is likely that few or none of these will be found in the analyzed publications. However, should they be? Sure, conservation is important for bioenergy production and food security, which dominate the news headlines, but shouldn't we also be hearing about concentrated solar (wind) power, demand for coconut water, or restoration with unmanned aerial vehicles if not in the mainstream media, then at least in the major conservation-

\section{Table 1}

2013 horizon issues in ecology

\section{Issues}

1. Rapid growth of concentrated solar power

2. Widespread development of thorium-fuelled nuclear power

3. Seabed-located oil drilling and processing

4. Accelerating water cycle

5. Proliferation of hydropower in the Andean Amazon

6. Species loss as a driver of global environmental change

7. Vegetation aquaculture feed

8. Rapid rise in global demand for coconut water

9. Detecting aquatic species with environmental DNA

10. Use of coral nurseries for reef restoration

11. Forest conservation and restoration by micro unmanned aerial vehicles

12. The 3D printing revolution

13. A link between biodiversity, allergy, and autoimmune disease

14. The commercial use of antimicrobial peptides 15. Synthetic genetics (Sutherland et al. 2013). 
related journals? More should be done by conservation-related societies to annually scan the horizon to find those things that are out of the ordinary, yet very important to what we as conservation professionals might have to deal with one day.

Maybe conservation-related societies will never have to deal with synthetic genetics or the 3D printing revolution, at least not directly. However, it would behoove them to identify how issues on the horizon might be applied to practice. They could start by selecting horizons most closely related to their interests from the results of a previous annual horizon scan (e.g., ecology or other). From this, it could be determined which are of immediate concern and warrant some type of action and for which action can be delayed until the issues develop and their relevance becomes more clear. This process would help in further advancing the missions of the major conservation-related societies, as well as the missions of other societies. It would help them in becoming credible as relied upon sources for what lies ahead in the area of conservation, and they would be able to embrace and lead in conservation as it has changed and will change in the future.

\section{REFERENCES}

Aspen Institute. 2012. Nature as Foundation of Economy: Investing in Natural Infrastructure for Conservation Supporting Human Development. Washington, DC: The Aspen Institute. http:// www.aspeninstitute.org/publications/ nature-foundation-economy-investing-naturalinfrastructure-conservation-supporting.

Interempresas. 2012. The robotics will revolutionise the agriculture. http://www.interempresas.net/ Agriculture/Articles/80686-New-autonomousrobots-will-reduce-use-pesticidas-in.html.
Studio 360. 2010. Aptera, Car of the Future. http:// www.studio360.org/2010/dec/31/apteracar-of-the-future.

Sutherland,W.J.,H.Allison, R.Aveling, I.P.Bainbridge, L. Bennun, D.J. Bullock, A. Clements, H.Q. Crick, D.W. Gibbons, S. Smith, M.R. Rands, P. Rose, J.P. Scharlemann, and M.S. Warren. 2012. Enhancing the value of horizon scanning through collaborative review. Oryx 46:368-374.

Sutherland, W.J., S. Bardsley, M. Clout, M.H. Depledge, L.V. Dicks, L. Fellman, E. Fleishman, D.W. Gibbons, B. Keim, F. Lickorish, C. Margerison, K.A. Monk, K. Norris, L.S. Peck, S.V. Prior, J.P. Scharlemann, M.D. Spalding, and A.R. Watkinson. 2013. A horizon scan of global conservation issues for 2013. Trends in Ecology \& Evolution 28:16-22. 